\title{
REFLEKSI HISTORIS PENDIDIKAN RASULULLAH Potret Untuk Pendidikan Karakter Anak Bangsa
}

\author{
Askar Ahmad \\ STAIN Datokarama Palu \\ askar@yahoo.com
}

Pendidikan karakter adalah kata kunci untuk membentuk dan memperkuat kepribadian anak bangsa. Kartakter yang kuat merupakan modal utama dalam mengembangkan bangsa yang berperadaban untuk memasuki percaturan dan persaingan yang semakin mengglobal. Bangsa yang berkarakter kuat sangat ditentukan oleh proses pendidikan. Proses pendidikan dan pembelajaran yang berkarakter merupakan kunci utama bagi terbentuknya kepribadian yang berkarakter, hal ini sebagaimana ditunjukkan oleh proses pendidikan dan pembelajaran yang dilalui dan dikembangkan oleh Rasulullah saw.

Kata kunci: Pendididikan Rasulullah, pendidikan karakter

\section{PENDAHULUAN}

UU No 20 Tahun 2003 Tentang Sistem Pendidikan Nasional pada Pasal 3, mengamanatkan bahwa pendidikan nasional berfungsi mengembangkan kemampuan dan membentuk karakter serta peradaban bangsa yang bermartabat dalam rangka mencerdaskan kehidupan bangsa. Pendidikan nasional bertujuan untuk berkembangnya potensi peserta didik agar menjadi manusia yang beriman dan bertakwa kepada Tuhan Yang Maha Esa, berakhlak mulia, sehat, berilmu, cakap, kreatif, mandiri, dan menjadi warga negara yang demokratis serta bertanggung jawab. ${ }^{1}$

Amanah UU Sisdiknas tahun 2003 itu, menunjukkan bahwa esensi pendidikan nasional adalah membentuk karakter anak bangsa yang berkepribadian dan berperadaban. Pendidikan nasional bertujuan untuk membentuk anak bangsa Indonesia yang cerdas, namun juga berkarakter, sehingga nantinya akan lahir generasi bangsa yang tumbuh berkembang dengan karakter yang bernafas nilai-nilai luhur bangsa serta agama. ${ }^{2}$ 
Keberhasilan pendidikan nasional tidak hanya dapat dilihat pada panguasaan ilmu pengetahuan tetapi juga anak bangsa yang berpendidikan dapat menujukkan karakter yang sesuai dengan budaya bangsa yang sesuai dengan nilai-nilai-nilai agama yang tumbuh dan berkembang di Indonesia dan nilai-nilai Pancasila.

Pembentukan karakter tidak saja untuk memperkuat jati diri dan identitas anak bangsa, tetapi juga untuk mengembangkan kepribadian yang berkarakter untuk memasuki pergaulan internasional yang semakin mengglobal. Realitas menunjukkan bahwa negara-negara yang memiliki karakter yang kuat, ternyata memiliki peradaban yang tinggi. Ini menunjukkan bahwa kemampuan kompetitif bangsa hanya dapat dicapai melalui karakter yang kuat dan beradab. ${ }^{3}$ Penguatan karakter ini sangat penting dalam membentuk akhlak anak bangsa Indonesia. Penguatan dan pengembangan karakter bukan hanya menjadi proses pembentukan watak bangsa, melainkan juga sebagai poros utama titik balik kesuksesan peradaban bangsa. ${ }^{4}$

Dalam perjalanan sejarahnya, Indonesia mengalami pasang surut perkembangan dan peradaban. Sejak mengalami masa krisis, terutama krisis ekonomi yang berlanjut pada krisis budaya dan politik bahkan krisis nilai, sehingga bangsa Indonesia mengalami penurunan peradaban, sekaligus kemunduran kualitas karakter. Hal ini sangat berpengaruh terhadap tatanan kehidupan berbangsa dan bernegara. Bangsa yang pada awalnya dikenal dengan bangsa yang memiliki kesopanan dan kesantunan, berubah menjadi bangsa yang mengedepankan kekasaran dan bahkan kekerasan. Nilai-nilai etika dan moral yang berbasis pada pancasila, budaya dan nilai-nilai universal agama semakin menipis dan digantikan oleh nilai-nilai primordial kesukuan, individualisme dan kepentingan tertentu atas nama agama. Hal ini semakin memacu munculnya tindakan kriminal di tengah masyarakat yang mengatas namakan suku atau kelompok tertentu, dan agama. Anak bangsa semakin kehilangan identitas dan karakter positif, disebabkan oleh semakin kaburnya orientasi nilai-nilai luhur bangsa. Kehidupan berbangsa dan bernegara semakin kehilangan dinamika dan keharmonisan.

Untuk mengatasi problem dalam kehidupan berbangsa dan bernegara, dan untuk ikut berperan serta dalam dinamika kehidupan global diperlukan adanya karakter bangsa yang kuat. Penguatan dan pengembangan karakter yang kuat meniscayakan adanya pendidikan secara sistematis dan berkesinambungan. Ini berarti bahwa revitalisasi pendidikan mutlak harus dilakukan untuk memberi ruang bagi pelaksanaan pendidikan karakter. Dalam konteks revitalisasi pendidikan untuk pendidikan karakter diperlukan adanya berbagai pola dan contoh yang dapat dikembangkan untuk 
pendidikan karakter anak bangsa. Dari sisi ini sangat penting untuk merefleksi pola pendidikan Rasulullah saw untuk kemudian dapat dijadikan pola pengembangan karakter di lembaga pendidikan.

\section{PENDIDIKAN RASULULLAH SAW.}

Catatan sejarah menunjukkan bahwa kerasulan Muhammad merupakan suatu fenomena yang luar biasa sehingga memberi pengaruh yang sangat kuat dalam mengubah kehidupan masyarakat Arab dan meninggalkan warisan di antara agama-agama besar dunia. Visi keagamaan dan perilaku keduniaan serta aktivitas Muhammad dilandasi oleh al-Qur'an. ${ }^{5}$ Ini menunjukkan bahwa kepribadian rasulullah yang sangat kuat dan mengagumkan sehingga sukses dengan risalah tauhid yang diembannya tidak terlepas dari bimbingan al-Qur'an dan lindungan Allah. Sekalipun demikian, secara rasional empiris terdapat pola-pola pendidikan yang dialami oleh rasulullah yang dapat diidentifikasi sebagai faktor penentu terbentuknya kepribadian yang mengagumkan dengan menonjolkan berbagai karakter yang sangat kuat dan menjadi penentu keberhasilan dalam kepemimpinannya.

Jika diidentifikasi dalam konteks sekarang, maka pola pendidikan yang dialami oleh nabi Muhammad sejak usia dini hingga dewasanya semuanya dilalui dalam jalur pendidikan informal dan non formal. Bermula dari pengasuhan dan pendidikan yang diberikan oleh ibunya, dengan penuh kasih sayang walau hanya sesaat. Aminah adalah sosok ibu yang memiliki kepribadian yang baik dengan kesucian akhlak dan kesederhanaannya. Ia berasal dari keturunan terhormat, ayahnya adalah salah seorang terkemuka yang dihormati oleh semua orang Bani Zuhrah. ${ }^{6}$ Abdullah ayah rasulullah merupakan sosok yang memiliki keteguhan pendirian, patuh dan tunduk pada orang tua. ${ }^{7}$

Wanita lain yang turut berpengaruh dalam perjalanan hidup Rasulullah adalah Halimatus Sa'diyah, seorang wanita dari keturunan Bani Sa'd bin Bakr. Halimatus Sa'diah sesuai dengan namanya sendiri, merupakan ibu yang memiliki perangai yang lemah lembut, ikhlas, senantiasa sabar dan tegar menghadapi kehidupan dan selalu merasa bahagia. Keterlibatan Halima dalam pengasuhan dan pendidikan Nabi Muhammad tidak terlepas dari tradisi budaya Arab ketika itu. Sudah menjadi kebiasaan bangsawan Arab ketika itu mempercayakan anakanaknya kepada wanita penyusu yang berasal dari kuar kota, sehingga anakanak mereka dapat dibesarkan di udara gurun yang segar sehingga dapat 
tumbuh kuat dan sehat. Anak-anak mereka juga dapat belajar bahasa Arab dengan baik. Para penyusu dari bani Sa'ad bin Bakr sangat terkenal di kawasan ini. ${ }^{8}$

Sebagai pengasuh dan pendidik Halimah memperlakukan Muhammad dengan penuh kasih sayang dan kelembutan, bahkan Halimah mengasuh dan mendidik Muhammad seperti anaknya sendiri. Halimah memberikan penghormatan dan penghargaan kepada anak susuannya tersebut dan memperlakukannya dengan sangat baik serta memberikan perlindungan. Teman-teman Muhammad diantaranya anak-anak Halimah sendiri, turut memperlakuan Muhammad seperti saudaranya sendiri. Halimah dan suaminya semakin menyayangi setelah merasakan limpahan berkah berupa kemakmuran serta limpahan harta dan ternak yang semakin banyak selama mengasuh dan mendidik Muhammad. ${ }^{9}$

Muhammad bermukim di lingkungan bani Sa'ad selama lima tahun lamanya dan merasakan lingkungan gurun sahara yang penuh kebebasan dan kemerdekaan. ${ }^{10}$ Kondisi gurun sahara tidak saja membentuk fisik nabi Muhammad menjadi fisik yang sehat dan kekar, sehingga Ia terhindar dari penyakit, tetapi juga telah menempa kejiwaannya sehingga kemandirian dan optimismenya terbentuk, tegar dalam menghadapi segala masalah yang dihadapinya. Suasana gurun juga menumbuhkan motivasi dan semangat kerja keras Nabi Muhammad. Lingkungan keluarga yang bersahaja, penuh keikhlasan, kelembutan dan kasih sayang, dan kejujuran secara lambat laun juga mewarnai karakter rasulullah saw.

Setelah kurang lebih lima tahun Nabi Muhammad berada dalam pengasuhan dan pendidikan Halimah, dan dengan terjadinya beberapa peristiwa yang dialami oleh Muhammad yang menjadikan Halimah dan suaminya khawatir akan keselamatan rasulullah, maka keluarga tersebut mengembalikan Muhammad kepangkuan ibunya yakni Aminah binti Abdul Manaf. Muhammad tidak banyak merasakan kasih sayang ibunya, karena belum berapa lama bersama, ibunya pun meninggal. Kondisi ini membuat Muhammad merasakan pilu dan derita serta kesedihan yang mendalam.

Sepeninggal ibunya Muhammad dipelihara oleh kakeknya Abdul Muttalib. Kakeknya memelihara dan mendidik secara sungguh-sungguh dan mencurahkan segala kasih sayangnya kepada Muhammad, bahkan memberikan perlakuan istimewa dan penghormatan melebihi anakanaknya. ${ }^{11}$ Abdul Muttalib sendiri adalah orang yang disegani di kalangan kaum Quraisy, teguh dalam memegang janji, dengan perikemanusiaan yang tinggi, bertanggung jawab, memiliki sifat adil dan peduli pada sesama. ${ }^{12}$ Ketika Muhammad berumur 10 tahun, Abdul Muttalib wafat, sehingga 
pengasuhan dan pendidikan nabi Muhammad dipercayakan kepada pamannya Abu Thalib. Sebagai pengasuh dan pendidik abu Thalib juga memberikan limpahan kasih sayang pada kemanakannya itu, Abu Thalib bersungguh-sungguh dengan penuh kelembutan untuk mendidik rasulullah. Abu Tahlib juga memiliki sikap hidup yang sederhana, sangat terkenal dengan kedermawanan dan kebaikannya. ${ }^{13}$

Selain pendidikan informal, Muhammad juga memperoleh pendidikan melalui jalur pendidikan non formal. Pendidikan non formal yang dilewati oleh Nabi Muhammad adalah menggembala kambing dan berdagang. Pekerjaannya menggembala kambing sejak kecilnya, baik menggembala kambing keluarganya maupun kambing penduduk Mekkah telah menempah karakternya menjadi karakter yang tangguh dan disiplin, ulet, sabar dan telaten.

Menggembala kambing di udara yang bebas dan lepas di siang hari, dan kemilau bintang bila malam sudah bertahta, menemukan suatu tempat yang serasi untuk pemikiran dan perenungan. Pemikiran dan perenungan yang demikian membuat ia jauh dari segala pemikiran nafsu duniawi, kepalsuan hidup dan kesia-siaan, sehingga perbuatan dan perilakunya terhindar dari segala noda dan dosa yang dapat merusak citra diri dan namanya, yang kemudian mengantarkannya sebagai seorang yang al-amin. Kehidupan menggembala kambing juga mengantarkannya pada suatu pola hidup sederhana dan jauh dari hidup serakah, memiliki kekayaan jiwa yang kuat sehingga mampu menyesuaikan diri dengan kehidupan batin. ${ }^{14}$ Muhammad juga memperoleh pembelajaran yang berharga dari kehidupannya menggembala kambing berupa kemampuan dan kedisiplinan, serta ketabahan dan kesabaran dalam memelihara kambing, mampu memikul kesukaran dan penderitaan yang kelak sangat berarti dalam menunaikan tugas kenabian dan kerasulannya, yang membutuhkan kesabaran, ketabahan dan keuletan dalam menuntun manusia. ${ }^{15}$

Melalui perdagangan Muhammad juga banyak memperoleh pendidikan dan pembelajaran. Pembelajaran tentang perdagangan diperoleh rasulullah dari pamannya Abu Thalib. Dengan berdagang Muhammad secara lambat laun menguasai keterampilan dan strategi perdagangan, mengetahui tentang cara-cara berdagang yang baik, cara-cara berkomunikasi dan berhubungan dagang dengan pelanggannya. Muhammad memahami dengan baik prinsip-prinsip perdagangan seperti kebenaran, kejujuran, keadilan, integritas serta sikap amanah. Prinsip-prinsip perdagangan seperti ini menjadikan Muhammad sukses dalam berbisnis dan memperoleh keuntungan yang optimal. ${ }^{16}$ Sifat-sifat ini pulahlah yang semakin menarik 
perhatian Khadijah untuk membangun kerjasama perdagangan yang pada akhirnya menikah dengan Nabi Muhammad. Kerjasama perdagangan dengan Khadijah memberi peluang kepada Nabi Muhammad untuk menerima berbagai pembelajaran sehingga usaha dagang yang dikelolanya semakin berkembang dan menjadi kerajaan bisnis yang sangat berhasil.

Khadijah sendiri adalah sosok wanita cerdas teguh pada pendirian, sehingga sekalipun banyak di kalangan keluarganya yang tidak setuju Ia kawin dengan Muhammad, namun dengan keteguhan pada keyakinannya akhirnya ia tetap melamar Muhammad. Selain itu Khadijah juga adalah sosok wanita yang suci, setia, sabar dalam mendampingi Rasulullah baik dalam suka maupun duka. ${ }^{17}$ Khadijah bukan saja wanita dan isteri teladan tetapi ia juga salah satu guru terbaik rasulullah saw.

Berbagai pola pendidikan yang diterima oleh rasulullah itu diimplementasikannya kembali setelah ia menjadi pendidik. Sebagai pendidik rasulullah adalah sosok yang mempunyai tekad, sifatnya sangat lembut dengan spiritualitas terdalam dan moralitas tertinggi. Rasulullah merepresentasikan dan mengekspresikan apa yang ingin dia ajarkan melalui tindakannya, dan kemudian menerjemahka tindakannya ke dalam kata-kata. Rasulullah memperhatikan dengan sungguh-sungguh kepada semua aspek dari pikiran, ruh dan sikap dan perilaku seseorang dan mendidiknya dengan sempurna dengan cara-cara yang sangat pantas. ${ }^{18}$

Muhammad sebagai manusia pebelajar telah melewati berbagai proses pendidikan dan pembelajaran yang telah menjadikan dirinya dan seluruh kepribadian dan karakternya menjadi uswatun khasanah. Tak dapat dipungkiri bahwa karakter rasulullah yang mengagumkan itu karena memang Ia dididik oleh Allah yang maha sempurna, selain itu secara rasional empiris rasulullah juga dididik oleh guru-guru terbaik yang memiliki karakter terbaik. Semua orang yang mengasuh dan mendidik rasulullah adalah manusia-manusia yang memiliki sifat dan karakter yang terbaik dan mengagumkan. Rasulullah dididik dalam susana dan lingkungan akademik yang juga berkarakter seperti suasana kelembutan, penuh kasih sayang, perlakuan yang baik, pemberian hak dan penghormatan dan suasana demokratis. Pembelajaran yang diterima juga adalah pembelajaran yang penuh dengan materi-materi pembentukan karakter yang tidak hanya menyentuh pada aspek akal, tetapi juga ruh dan perilaku. Pola pembelajaran tidak hanya melalui tatap muka tetapi juga melalui praktek langsung sebagaimana dilakukan oleh rasulullah ketika menggembala kambing dan berdagang. Ini menunjukkan bahwa jika suatu lembaga pendidikan memiliki misi untuk pendidikan karakter, maka yang perlu diperhatikan 
adalah, bahwa lembaga pendidikan tersebut memiliki guru-guru yang berkarakter terbaik, membentuk suasana dan lingkungan akademik atau iklim akademik yang berkarakter, kurikulum dan pembelajaran yang berkarakter, dan memberi kesempatan kepada peserta didik untuk mengimplementasikan seluruh pendidikan karakter yang diterimanya dalam praktek kehidupan, sebagai upaya agar peserta didik dapat merasakan manfaat dari pendidikan karakter yang telah diterimanya.

\section{PENDIDIKAN KARAKTER ANAK BANGSA}

Karakter merujuk pada cara berpikir dan berperilaku yang menjadi ciri khas tiap individu untuk hidup dan bekerjasama, baik dalam lingkup keluarga, masyarakat, bangsa dan negara. Individu yang berkarakter baik adalah individu yang bisa membuat keputusan dan siap mempertanggungjawabkan tiap akibat dari keputusan yang ia buat. ${ }^{19}$ Sedangkan pendidikan karakter adalah suatu sistem penanaman nilai-nilai karakter kepada warga sekolah yang meliputi komponen pengetahuan, kesadaran atau kemauan, dan tindakan untuk melaksanakan nilai-nilai tersebut, baik terhadap Tuhan Yang Maha Esa (YME), diri sendiri, sesama, lingkungan, maupun kebangsaan sehingga menjadi manusia insan kamil. ${ }^{20}$

Tujuan pendidikan karakter adalah untuk pembentukan karakter yang terwujud dalam kesatuan esensial peserta didik dengan perilaku dan sikap hidup yang dimilikinya. Karakter merupakan sesuatu yang mengualifikasi seorang pribadi. Karakter menjadi identitas yang mengatasi pengalaman kontingen yang selalu berubah. Dari kematangan karakter inilah, kualitas seorang pribadi diukur. Pendidikan karakter menekankan pada dimensi etisspiritual dalam proses pembentukan pribadi. $^{21}$

Banyak rumusan tentang karakter-karakter positif yang semestinya ditumbuh kembangkan dalam pendidikan karakter. Michael Josephson pendiri Josephson Institut of Etihc di Amerika, merumuskan bahwa secara garis besar ada enam pilar karakter (the six pillars of character) yang semestinya ditumbuh kembangkan dalam diri peserta didik, yaitu; 1) kepercayaan (trustworthiness), berlaku jujur, terpercaya, sesuainya kata dengan perbuatan, berani karena benar, membangun reputasi yang baik, mencintai keluarga dan setia pada negara; 2) Sikap hormat (respect), hormat terhadap orang lain, taat hukum, toleran dalam perbedaan, berlaku sopan dan berbahasa santun, empatik, tidak menjadi ancaman bagi orang lain, dan bersikap damai; 3) bertanggung jawab (responsibility), berorientasi masa depan, tekun dalam kebaikan, disiplin dan mawas diri, berpikir sebelum 
bertindak dan siap menerima konsekwensi tindakan, bertanggung jawab atas perkataan dan perbuatannya, menjadi contoh bagi orang lain; 4) bersikap adil (fairness), bertindak sesuai aturan, berpikiran terbuka dan mendengarkan orang lain, tidak mengeksploitasi orang lain, meperlakukan semua orang dengan adil, 5) penuh perhatian (caring), perhatian dan penuh kasih sayang, peduli terhadap orang lain, memiliki sikap memaafkan, memberi bantuan pada orang yang membutuhkan, 6) menjadi warga negara yang baik (citizenship), memasyarakat, mampu bekerja sama, menghormati orang lain, mencintai dan melindungi lingkungan, rela berkorban. ${ }^{22}$

Rumusan yang relatif sama dengan redaksi yang berbeda dikemukakan pula oleh pakar dari UI. Menurut para perumusnya bahwa ada enam aspek karakter yang seharusnya dimiliki peserta didik. Keenan aspek tersebut adalah; 1) kebijaksanaan dan pengetahuan, meliputi, kreativitas (keunikan dan kesungguhan), keingintahuan (minat, mencari kebaharuan, terbuka terhadap pengalaman), keterbukaan (penilaian, berpikir kritis), kecintaan akan belajar, perspektif (kebijaksanaan); 2) keberanian terdiri dari ,kekesatriaan, kegigihan (ketabahan, rajin), integritas (keaslian, kejujuran), vitalitas (antusiasme, energi); 3) kemanusiaan terdiri dari, cinta-kasih, kebaikan (kemurahan hati, membina, kepedulian, welas asih, cinta tanpa pamrih, keramahan), inteligensi sosial (inteligensi emosional, inteligensi personal); 4) keadilan terdiri dari, kewarganegaraan (tanggung jawab sosial, kesetiaan, kerjasama), kesetaraan, kepemimpinan; 5) kendali diri terdiri dari, memaafkan dan mengasihani, kerendahan hati dan kesederhanaan, prudence, pengelolaan diri; 6) transendensi terdiri dari, apresiasi terhadap keindahan dan kesempurnaan), rasa syukur, harapan (optimisme, berpikiran dan berorientasi pada masa depan), humor (kejenakaan), spiritualitas (keagamaan, keyakinan, bertujuan). ${ }^{23}$

Gerakan nasional pendidikan karakter di Indonesia merumuskan bahwa secara garis besar pendidikan karakter bertujuan untuk; 1) membentuk manusia Indonesia harus bermoral, berahlak, dan berperilaku baik. Oleh karena itu masyarakat diimbau menjadi masyarakat religius yang anti kekerasan, 2) membentuk bangsa Indonesia menjadi bangsa yang cerdas dan rasional. Berpengetahuan dan memiliki daya nalar tinggi, 3) membentuk bangsa Indonesia menjadi bangsa yang inovatif dan mengejar kemajuan serta bekerja keras mengubah keadaan, 4) memperkuat semangat harus bisa, dan 5) menjadi patriot sejati yang mencintai bangsa dan negara serta tanah airnya. ${ }^{24}$

Profil karakter positif sebagaimana telah dikemukakan semua tercermin dalam pribadi Rasulullah saw. Jika merujuk pada pribadi 
rasulullah, maka secara umum karakter-karakter yang menonjol adalah kejujuran, ketegaran, kesabaran, semangat kerja keras, sikap menghargai dan menghormati antar sesama, santun dalam tutur kata, anggun dalam bertindak, bertanggng jawab, pengasih dan penyayang dan lebih penting dari itu semua adalah ketundukan dan kepasrahan serta keteguhan aqidahnya kepada Allah. Harus diakui bahwa pribadi rasulullah adalah pribadi yang paripurna dan sangat sulit untuk diikuti dan diteladani sepenuhnya, namun demikian bukan berarti bahwa keseluruhan pribadi rasulullah tersebut tidak bisa diikuti.

Sekalipun pendidikan karakter merupakan suatu gerakan nasional dalam upaya pengembangan karakter dan pembentukan kepribadian bangsa, tetapi bukan berarti bahwa pendidikan karakter memiliki program-program secara spesifik di lembaga pendidikan. Pendidikan karakter tidak harus membutuhkan mata pelajaran tersendiri, atau program khusus dalam kegiatan ekstrakurikuler, dan atau penggabungan antar keduanya. Pendidikan karakter semestinya dilakukan secara holistik, yaitu sebuah model penerapan pendidikan karakter yang melibatkan aspek pengetahuan (cognitive), perasaan (feeling), dan tindakan (action), dengan metode knowing the good, feeling the good, dan acting the good. Knowing the good bisa mudah diajarkan sebab pengetahuan bersifat kognitif saja. Setelah knowing the good harus ditumbuhkan feeling loving the good, yakni bagaimana merasakan dan mencintai kebajikan menjadi engine yang bisa membuat orang senantiasa mau berbuat sesuatu kebaikan. Sehingga tumbuh kesadaran bahwa, orang mau melakukan perilaku kebajikan karena dia cinta dengan perilaku kebajikan itu. Setelah terbiasa melakukan kebajikan, maka acting the good itu berubah menjadi kebiasaan. ${ }^{25}$

Jika merujuk pada pola pendidikan yang dilalui dan diperaktekkan oleh rasulullah Muhammad saw, maka ditemukan bahwa pendidikan katakter dialkukan secara holistik. Holitik yang dimaksud di sini tidak hanya sekedar memberi pengetahuan, perasaan dan tindakan, tetapi menyentuh pada semua aspek yang memungkinkan karakter positif tumbuh dan berkembang dalam diri peserta didik. Pendidikan karakter di masa Nabi Muhammad saw, tidak hanya sekedar memberikan pengetahuan, tetapi juga menunjukkan karakter positif (showing the good) dalam artian bahwa para pendidik tidak hanya sekedar menanamkan pengetahuan, tetapi juga menjadi model, yakni guru senantiasa menunjukkan dan mempraktekkan karakter-karakter positif yang dapat diteladani oleh para peserta didik. Guru dituntut untuk senantiasa mepertunjukkan kesabaran, keikhlasan, kesungguhan, kejujuran, menunjukkan rasa kasih sayang kepada peserta 
didiknya dalam mendidik, Ini berati bahwa guru dituntut untuk memiliki keluasan ilmu pengetahuan, namun pada saat yang sama ia juga dituntut untuk memiliki kedalam spiritual dan keluhuran budi pekerti.

Untuk menumbuhkan karakter positif dalam diri peserta didik semestinya dilakukan melalui proses pembelajaran yang beroriantasi pada penyadaran, pembelajaran, pembiasaan atau pembatinan. ${ }^{26}$ Proses penyadaram mengubah peserta didik dari situasi tidak siap/tidak mau belajar menjadi siap dan mau belajar, dengan menata ulang aspek kehendak, afeksi, sikap mental, dengan mengkonstruksi pikiran tertetu yang membuka peluang bagi orang tersebut untuk mengalami transformasi diri. Proses pembelajaran mengubah peserta didik dari tidak bisa menjadi bisa dan berkemampuan dengan menata ulang aspek pengetahuan (kognitif) dan keterampilan wilayah logos dan kinestetik, dengan memberi informasi pengetahuan atau pelatihan untuk menambah pengetahuan dan memperkuat keterampilan. Proses pembiasaan mengubah peserta didik dari sekedar bisa menjadi profesional dengan menata ulang karakter watak, wilayah etos dengan memandu proses pengulangan pola pikir dan prilaku agar menjadi bagian dari diri peserta didik. ${ }^{27}$ Proses penyadaran, pembelajaran dan pembatinan melalui perenungan inilah yang kemudian menjadikan Nabi tidak hanya memiliki pengetahuan dan keterampilan tetapi juga memiliki kemampuan olah batin yang kemudian menjadikan Rasulullah memiliki karakater positif dalam dirinya, yang menyebabkannya selalu disenangi oleh kawan (para sahabat) dan disegani oleh para "lawannya".

Selain faktor guru, dan pola pembelajaran, pendidikan karakter di masa nabi juga didukung oleh lingkungan yang baik (envirounment the good). Faktor lingkungan baik lingkungan fisik, maupun lingkungan non fisik, juga sangat menentukan tumbuh kembangnya karakter positif dalam diri peserta didik. Hal ini menunutut adanya penataan lingkungan, seperti suasana akademik, layanan administrasi, organisasi dan kepemimpinan yang memungkikan karakter-karakter positif peserta didik tumbuh dan berkembang dengan baik. Lingkungan yang baik tidak hanya menumbuh kembangkan karakter positif dalam diri peserta didik, tetapi sekaligus juga peserta didik dapat merasakan faedah dan manfaat dari karakter-karakter positif yang dipraktekkan. Siswa yang berbuat jujur dapat merasakan manfaat dari kejujurannya. Siswa yang disiplin dapat merasakan manfaat dari kedisiplinannya, sebagaimana rasulullah merasakan manfaat kejujurannya dalam berdagang sehingga relasinya semakin percaya dan semakin bertambah dan kerajaan bisnisnya semakin berkembang.

Dapat dikatakan bahwa pendidikan karakter di lembaga pendidikan 
tidak harus dilakukan melalui program khusus, atau diterapkan dalam mata pelajaran tertentu, tetapi pendidikan karakter semestinya dilakukan secara holistik dalam semua proses pendidikan. Pendidikan karakter semestinya tercantum dengan jelas dalam kurikulum, yang kemudian dirumuskan dicantumkan dalam semua mata pelajaran, yang dirumuskan dengan jelas dalam rencana pelaksanaan pembelajaran, serta diterapkan dalam pelaksanaan pembelajaran. Selain melalui pembelajaran di kelas, pendidikan karakter juga semestinya diimplementasikan dalam seluruh kegiatan ekstra kurikuler dan didukung oleh tenga pendidik yang memiliki kapasistas dan keteladanan prilaku, pola pembelajaran, serta lingkungan yang kondusif bagi tumbuh kembangnya karakter-karakter positif dalam diri peserta didik.

\section{PENUTUP}

Uraian terdahulu menunjukkan bahwa karakter positif sebagai faktor penting dalam memacu tumbuh kembangnya peradaban bangsa, hanya dapat ditumbuhkan melalui pendidikan yang berkarakter, didukung kurikulum dan pembelajaran yang berkarakter, pendidik yang berkarakter, lingkungan yang berkarakter. Karakter yang kuat pada semua faktor-faktor determinan pendidikan akan menentukan lahirnya peserta didik, lahirnya anak bangsa yang berkarakter yang berbasis pada nilai-nilai universal, etika kemanusiaan, nilai-nilai luhur bangsa dan nilai-nilai moral agama.[]

\section{Catatan Akhir:}

*Dr. Askar Ahmad, MA. adalah Dosen Jurusan Tarbiyah STAIN Datokarama Palu.

${ }^{1}$ Undang-Undang Sistem Pendidikan Nasional No. 20 tahun 2003 (Jakarta: Departemen Agama RI, 2007), h. 2.

${ }^{2}$ Suyanto, Urgensi Pendidikan Karakter, http://mandikdasmen.kemdiknas.go.id. Diakses tanggal, 1 Juli 2011.

${ }^{3}$ Miranda Diponegoro Z, dkk. Model Pendidikan Karakter di Universitas Indonesia, http://www.dikti.go.id, di akses tanggal 28 Juni 2011

${ }^{4}$ Pendidikan Karakter Sebagai Pondasi Kesuksesan Peradaban Bangsa, http://www.dikti.go.id. diakses, tanggal 2 Juli 2011

${ }_{5}^{5}$ Ira M. Lapidus, A Histori of islamic Societies. Diterjemahkan oleh, Ghufron A. Mas'adi, Sejarah Sosial Ummat Islam. (Jakarta: Raja Grafindo Persada, 2000), h. 29

${ }^{6} J a ' f a r$ Subhani, The Massage, Diterjemahkan oleh, Muhammad Hasyim dan Meth Kieraha, Ar-Risalah, Sejarah Kehidupan Rasulullah saw. (Jakarta: Lentera Basritama, 2000), h. 95 
${ }^{7}$ Syaikh Shafiyyur Rahman al-Mubarakfury, Ar-Rahiqul Maktum, Bahtsun Fissirah An-Nabawiyah Ala Shahibiha Afdhalish-Shalati Was-Salam, diterjemahkan oleh, Kathur Suhardi, Sirah Nabawiyah,(Jakarta: Pustaka al-Kautsar, 2001), h. 73

${ }^{8} \mathrm{Ja}$ 'far Subhani, The Message., h. 103

${ }^{9}$ Ibid., h. 106

${ }^{10}$ Muhammad Husain Haekal, Sejarah Hidup Muhammad, (Jakarta: Pustaka Litera Antarnusa, 1999), h. 53.

${ }^{11}$ H.M.H. Al-Hamid Al-Husaini, Membangun Peradaban, sejarah Muhammad Saw, Sejak Sebelum Diutus Menjadi Nabi. (Bandung: Pustaka Hidayah, 2000), h. 210-211.

${ }^{12}$ Ja'far Subhani, The Message, h. 75-79.

${ }^{13}$ Ibid. h. 112

${ }^{14}$ Muhammad Husain Haikal, Sejarah Hidup Muhammad, h. 60-61.

${ }^{15}$ Ja'far Subhani, The Message, h. 125.

${ }^{16}$ Muhammad Sebagai Syariah Marketer, http://www.koperasisyariah.com., di akses tanggal, 3 Juli 2011.

${ }^{17}$ Muhammad Husain Haikal, Sejarah Hidup Muhammad, h. 128-129

${ }^{18}$ M. Fethullah Gülen, Versi Terdalam Kehidupan rasul Allah Muhammad SAW, terj. Tri Wibowo Budi Santoso, (Jakarta: RajaGrafindo Persada, 2002), h. 197-199.

${ }^{19}$ Suyanto, Urgensi Pendidikan Karakter, http://mandikdasmen.kemdiknas.go.id. Diakses tanggal, 1 Juli 2011.

${ }^{20}$ Akhmad Sudradjat, Pendidikan Karakter, http://akhmadsudrajat.wordpress.com., diakses tanggal, 2 Juli 2011

${ }^{21}$ Doni Koesoema, A. Pendidikan Karakter, http://www.asmakmalaikat.com/ go/artikel/ pendidikan/umum1.htm, diakses tanggal 2 Juli 2011.

${ }^{22}$ Michael Josepshon, The Six Pillars of Character, http://charactercounts. org/sixpillars.html, diakses tanggal 6 juli 2011.

${ }^{23}$ Miranda Diponegoro Z, dkk. Model Pendidikan Karakter, h. 11-12

${ }^{24}$ Lima Tujuan Gerakan Pendidikan Karakter, http://nasional.kompas.com, di akses tanggal 2 Juli 2011.

${ }^{25}$ Suyanto, Pendidikan Karakter, http://akhmadsudrajat.wordpress.com., diakses tanggal, 2 Juli 2011.

${ }^{26}$ Andrias Harefa, Mindset Therapy, Terapi Pola Pikir, tentang Makna Learn, Unlearn, dan Relearn, (Jakarta: Gramedia Pustaka Utama, 2002), h. xiv.

${ }^{27}$ Ibid. h. xv

\section{DAFTAR PUSTAKA}


Diponegoro Z., Miranda dkk, Model Pendidikan Karakter di Universitas Indonesia, http://www.dikti.go.id. di akses tanggal 28 Juni 2011

Gülen, M. Fethullah, Prophet Muhammad Aspect of His Life, diterjemahkan oleh Tri Wibowo Budi Santoso, Versi Terdalam, Kehidupan rasul Allah Muhammad SAW. (Jakarta: RajaGrafindo Persada, 2002).

Haekal, Muhammad Husain, Hayat Muhammad. Diterjemahkan oleh, Ali Audah, Sejarah Hidup Muhammad, (Jakarta: Pustaka Litera Antarnusa, 1999).

Harefa, Andrias, Mindset Therapy, Terapi Pola Pikir, tentang Makna Learn, Unlearn, dan Relearn, (Jakarta: Gramedia Pustaka Utama, 2002).

al-Husaini, H.M.H. al-Hamid, Membangun Peradaban, sejarah Muhammad Saw, Sejak Sebelum Diutus Menjadi Nabi. (Bandung: Pustaka Hidayah, 2000), h. 210-211.

Josepshon, Michael, The Six Pillars of Character http:// charactercounts.org/sixpillars.html diakses tanggal 6 juli 2011.

Koesoema A, Doni, Pendidikan Karakter, http://www.asmakmalaikat. com/go/artikel/ pendidikan/umum1.htm, di akses tanggal 2 Juli 2011 .

Lapidus, Ira M., A History of Islamic Societies. Diterjemahkan oleh, Ghufron A. Mas'adi, Sejarah Sosial Ummat Islam, (Jakarta: RajaGrafindo Persada, 2000), h. 29

Lima Tujuan Gerakan Pendidikan Karakter, http://nasional.kompas.com, di akses tanggal 2 Juli 2011.

Mubarakfury, Syaikh Shafiyyur Rahman, Sirah Nabawiyah, (Jakarta: Pustaka al-Kautsar, 2001).

Muhammad Sebagai Syariah Marketer, http://www.koperasisyariah. com., di akses tanggal, 3 Juli 2011.

Pendidikan Karakter Sebagai Pondasi Kesuksesan Peradaban Bangsa, http://www.dikti.go.id. Diakses, tanggal 2 Juli 2011

Subhani, Ja'far, The Massage, Diterjemahkan oleh, Muhammad Hasyim dan Meth Kieraha, Ar-Risalah, Sejarah Kehidupan Rasulullah saw. (Jakarta: Lentera Basritama, 2000).

Sudradjat, Akhmad, Pendidikan Karakter, http://akhmadsudrajat. wordpress.com. Diakses tanggal, 2 Juli 2011 
Suyanto, Urgensi Pendidikan Karakter, http://mandikdasmen. kemdiknas.go.id. Diakses tanggal, 1 Juli 2011.

Undang-Undang Sistem Pendidikan Nasional No. 20 tahun 2003 (Jakarta: Departemen Agama RI, 2007). 